\title{
Volcano Hazards of the Lassen Volcanic National Park
} Area, California

n May 1915, Lassen Peak,
California, the southern-
most active volcano in the Cas-
cade Range, erupted explo-
sively. Avalanches, mudflows,
and flows of hot ash and gas
devastated nearby areas, and
volcanic ash fell as far away as
200 miles to the east. The
Lassen area remains volcani-
cally active, and the volcano
hazards demonstrated in 1915
still can threaten not only
nearby areas but also more dis-
tant communities. Recent work
by scientists with the U.S. Geo-
logical Survey (USGS) in coop-
eration with the National Park
Service is shedding new light
on these hazards.

On the night of May 19, 1915, the few people homesteading outside of Old Station along Hat Creek near the foot of Lassen Peak, a volcano in northern California, went to bed expecting a peaceful night's sleep. By now they had become accustomed to the sounds of small steam explosions coming from the volcano, which had been intermittently active during the past year. Around midnight, Elmer Sorahan was awakened by his dog barking furiously and pawing him. Dressing quickly, Elmer went outside, expecting a bear or other animal. Instead, he dimly saw a 12-foothigh wall of muddy water and logs rumbling down Hat Creek. After running more than a mile to warn his downstream neighbors, the Halls, he burst through their front door exhausted and shouting "Get out! get out! there's a flood coming." Mrs. Hall quickly spread the alarm downstream by telephone, and then the family scrambled uphill just before the house was swept off its foundation.

The next morning residents of the area saw that a wide swath of the northeast slope of Lassen Peak had been devastated by a huge

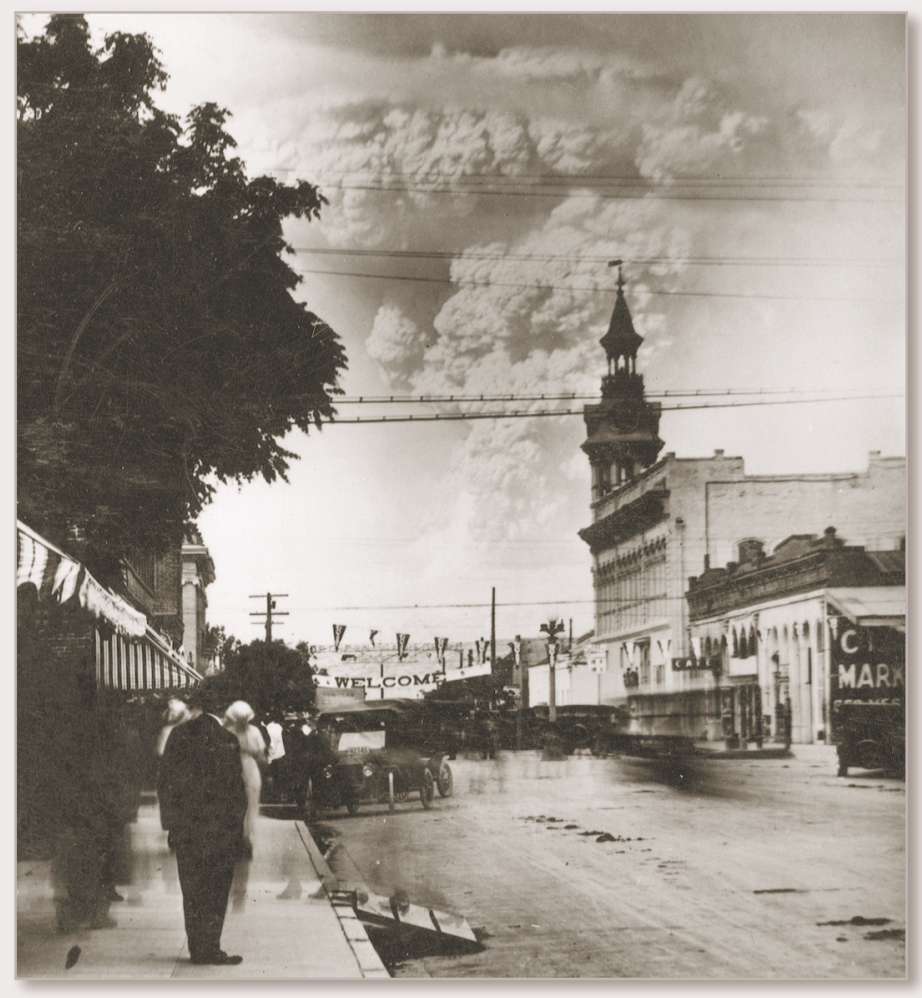

The May 22, 1915, explosive eruption of Lassen Peak, California, blasted pumice and rock fragments high into the air. In this photograph taken from the town of Red Bluff, 40 miles west of the volcano, a huge column of volcanic ash and gas produced by the eruption rises to a height of more than 30,000 feet. Winds blew volcanic ash eastward from the column, raining fine ash at least as far away as Winnemucca, Nevada, 200 miles from the volcano. The ash cloud from a similar eruption today would pose a serious hazard to flying aircraft in the Western United States. (Photo by R.E. Stinson; courtesy National Park Service.) avalanche and mudflow triggered by a powerful explosion at the volcano's summit. Fortunately, because of the warnings, no one was killed, but several houses along the creek were destroyed. When Lassen Peak erupted again on May 22nd, the area was further devastated by a high-speed flow of hot volcanic ash and gas (called a "pyroclastic flow"), and the incorporation of snow into this flow generated new mudflows. Ash from the eruption rose high into the air and wind blew it eastward. Fine ash fell at least as far as 200 miles from the volcano. Because of the eruptive activity, which continued through 1917, and the area's stark volcanic beauty, Lassen Peak and the area surrounding it were declared a National Park in 1916.

\section{Volcanic history of the Lassen Volcanic National Park region}

The Lassen region has been volcanically active for about 3 million years. Lassen Peak and nearby volcanic domes are the most recently active parts of the Lassen "volcanic center," which began to erupt about 600,000 years ago.
From 600,000 to 400,000 years ago, eruptions built a large conical volcano, often referred to as "Brokeoff Volcano" or "Mount Tehama," which was roughly the size of Mount St. Helens, Washington. Later, this volcano became inactive and was mostly eroded away, leaving remnants that include Brokeoff Mountain, Mount Conard,

Mount Diller, and Diamond Peak.

Subsequent eruptions from the Lassen volcanic center have formed more than 30 steepsided, mound-shaped accumulations of volcanic rock, called "lava domes." Eruptions about 27,000 years ago formed Lassen Peak, one of the largest lava domes on Earth. When Lassen Peak formed, it looked much like the nearby 1,100-year-old Chaos Crags domes, with steep sides covered by angular rock talus. However, from 25,000 to 18,000 years ago, during the last ice age, Lassen Peak's shape was significantly altered by glacial erosion.

Lassen Peak and its neighboring lava domes are not typical, conical "stratovolcanoes" like Mount Shasta or Mount Rainier. Those large volcanoes were formed by repeated eruptions 

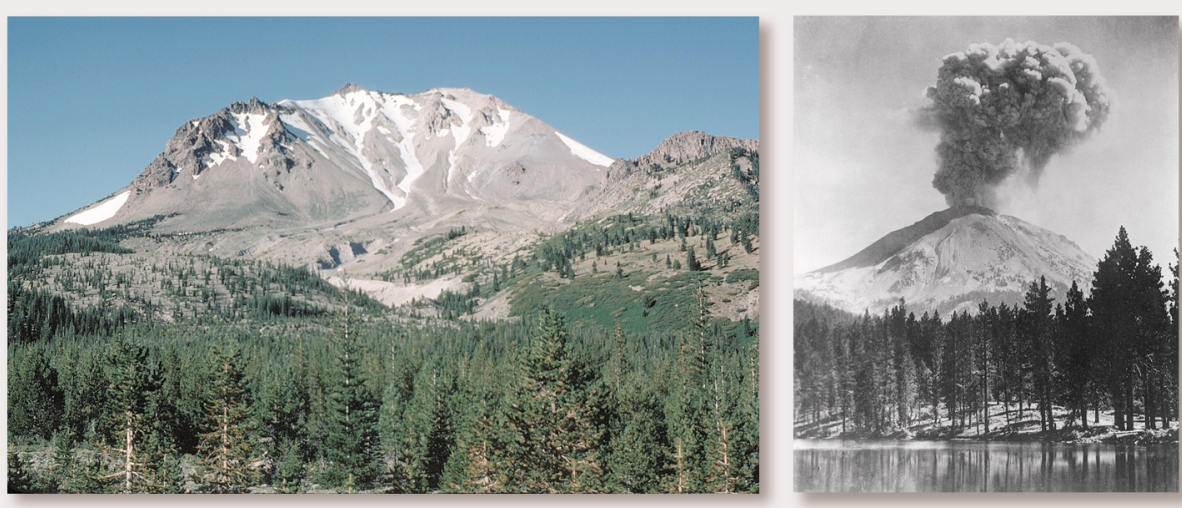

The northeast side of Lassen Peak still shows the scars of its 1914 to 1917 series of eruptions. The strongest of these eruptions in May 1915 destroyed a 3-square-mile area, now called the Devastated Area. Photo at right shows the peak in eruption in October 1915 (photo by Chester Mullen; courtesy National Park Service).

of lava and ash from a central summit vent over tens of thousands of years. The Lassen dome field, in contrast, is an example of a volcanic area that erupts lava from numerous individual vents, each of which is active for a few years to a few decades and usually does not erupt again.

The composition of the molten rock (magma) that feeds volcanism in the Lassen area ranges widely in its content of silica $\left(\mathrm{SiO}_{2}\right)$. When highsilica (dacite) magma rises to the Earth's surface, it can erupt explosively to produce ash clouds and pyroclastic flows. Dacite magma extruded nonexplosively forms lava domes, because it is too viscous to flow far away from its source. Low-silica (basalt) magma is more fluid and usually erupts less explosively than dacite magma. Eruptions of basalt magma typically produce elongate lava flows, as well as build cinder cones (piles of small frothy lava fragments or "cinders") around volcanic vents.

In the past 50,000 years, at least seven major episodes of dacitic volcanism produced lava domes and pyroclastic deposits in the Lassen area, and another five episodes produced basaltic and andesitic (silica content between basalt and dacite) lava flows. In addition, about 30 smaller volcanoes erupted basaltic lavas in the larger region surrounding the Lassen volcanic center.

\section{What are the hazardous volcanic processes of the Lassen area?}

The most common volcanic activity in the Lassen Peak region consists of small to moderate-sized eruptions that produce basaltic lava flows and localized ash falls. These eruptions typically last a few months to a year, but may continue for several years. They can cover more than a square mile with lava flows, build cinder cones as high as 1,000 feet, and blanket many square miles with ash a few inches to several feet deep. Because these eruptions are relatively nonviolent, they rarely cause human fatalities.

Basaltic volcanism in the Lassen area occurs mainly along chains of vents aligned in a north or northwest direction, parallel to regional faults. Examples include Poison Buttes, Subglacial Buttes, Tumble Buttes, the Prospect Peak-Red Cinder area, the east side of the Hat Creek Valley and Potato Buttes-Sugarloaf area, and the Red Lake Mountain area. Prolonged basaltic volcanism at a single site can produce a sizeable edifice, like the broad, relatively flat "shield" volcanoes of Prospect Peak and Sifford Mountain.

Dacite eruptions in the Lassen area typically begin with steam explosions caused by the interaction of rising magma with ground water. When dacite magma charged with volcanic gases reaches the surface, it erupts explosively, usually as a vertical column of gas and ash that can rise several miles into the atmosphere. Heavy fallback of hot ash and rock fragments from eruption columns may generate highly mobile pyroclastic flows that can rush several miles down a volcano's slopes and adjacent valleys. Fallout from the eruption column can blanket areas within a few miles of the vent with a thick layer of pumice, and high-altitude winds may carry finer ash tens to hundreds of miles from the volcano, posing a hazard to flying aircraft, particularly those with jet engines.

After an initial explosive eruption, extrusion of gas-depleted dacite magma commonly forms lava domes. Growing lava domes are inherently unstable, and collapse of their steep sides often generates pyroclastic flows of lava blocks and ash that can travel several miles. Such a sequence of events is recorded by the deposits related to the emplacement of Chaos Crags domes between 1,100 and 1,000 years ago.

Interaction of hot pyroclastic flows with snow and ice can generate highly mobile flows of mud and debris (called "lahars") that may rush down valleys leading away from a volcano. Because of this, active volcanoes that have a significant snow and ice cover can be particularly dangerous. The lahars that threatened residents of the Lassen area in May 1915 were generated by relatively small eruptions of Lassen Peak. Nonetheless, they traveled down creek beds as far as 12 miles and released floods that affected valleys for 30 miles downstream.

\section{What non-eruptive volcano hazards are important in the Lassen area?}

Additional volcano hazards at Lassen are rockfalls and landslides not directly related to eruptions. Recently erupted volcanic domes are unstable and can collapse, generating small to large rockfalls. Approximately 350 years ago, collapse of one of the Chaos Crags domes generated huge rockfalls, creating an area now called the Chaos Jumbles. The first and largest of these traveled 4 miles downslope and was able to climb 400 feet up the side of Table Mountain. The trigger for the rockfall is unknown, but it was most likely a large earthquake. Normal weathering also weakens fractured volcanic rock and contributes to small rockfalls. In the summer of 1994, a rockfall of 13,000 cubic yards (the volume of about 500 minivans) occurred on the northeastern flank of Lassen Peak. During periods of extreme rainfall or snow melt, mudflows

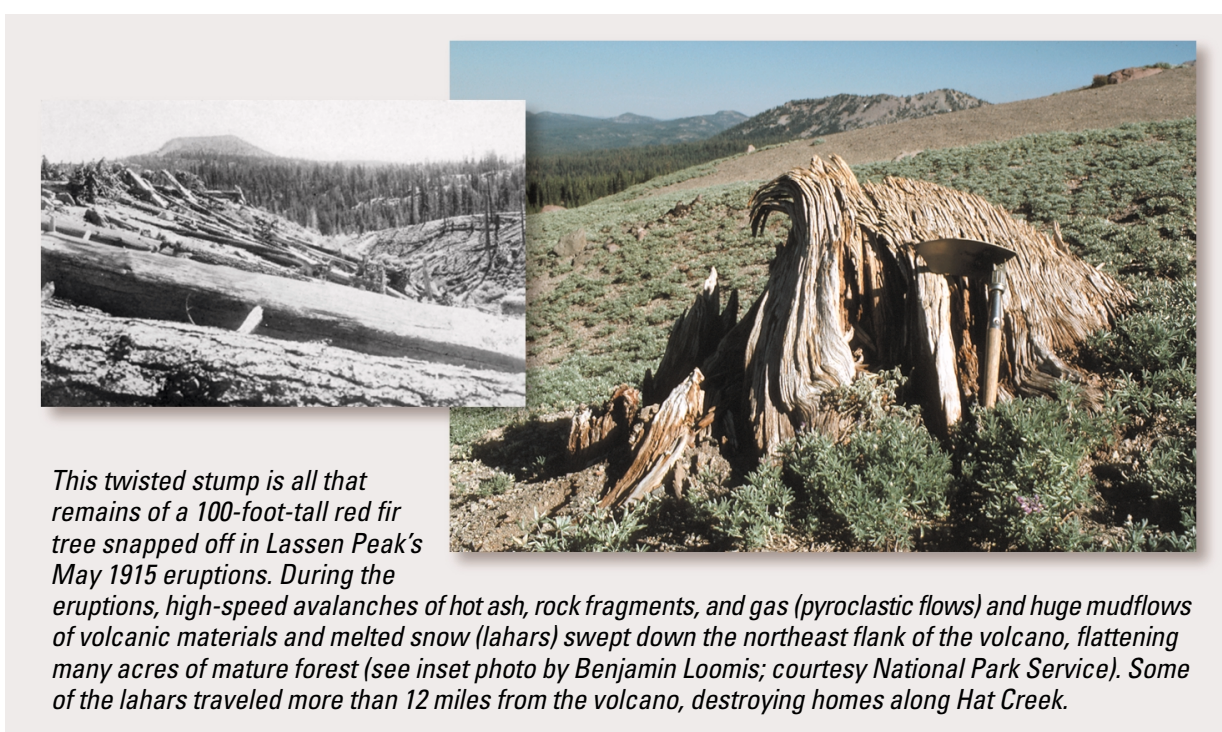


are sometimes generated by mobilization of loose volcanic debris and soil on the slopes of volcanoes.

\section{Where are the most hazardous areas?}

Volcano hazards are generally evaluated on the basis of an area's record of eruptions over the past 10,000 years, because future eruptions are most likely to occur near areas that have most recently had volcanic activity. However, in the Lassen region eruptions occur infrequently, so the record of activity in the past 50,000 years was used to provide an adequate basis for defining hazard zones. During this period, eruptions in the Lassen region have occurred at sites including Lassen Peak, Chaos Crags, and Sunflower Flat (explosive dacite eruptions followed by dome growth) and Tumble Buttes, Hat Mountain, and Prospect Peak (basalt eruptions). The areas of highest hazard are those that could be affected by pyroclastic flows and mudflows (see map). These areas, including Hat Creek Valley, are those in the immediate vicinity and downhill from likely eruption sites. Fallout of ash will affect areas downwind at the time of an eruption. Within the hazard zones, relative hazard is gradational, decreasing away from the location of potential vents.

\section{What are the prospects for future erup- tions at Lassen?}

Because geologically recent volcanic activity in an area is the best guide to forecasting future eruptions, scientists study the lava flows, ash, and other deposits from past eruptions. Volcanoes in the Lassen area tend to erupt infrequently, and may be inactive for periods lasting centuries or even millennia. The most recent eruptions in the Lassen area were the relatively small events that

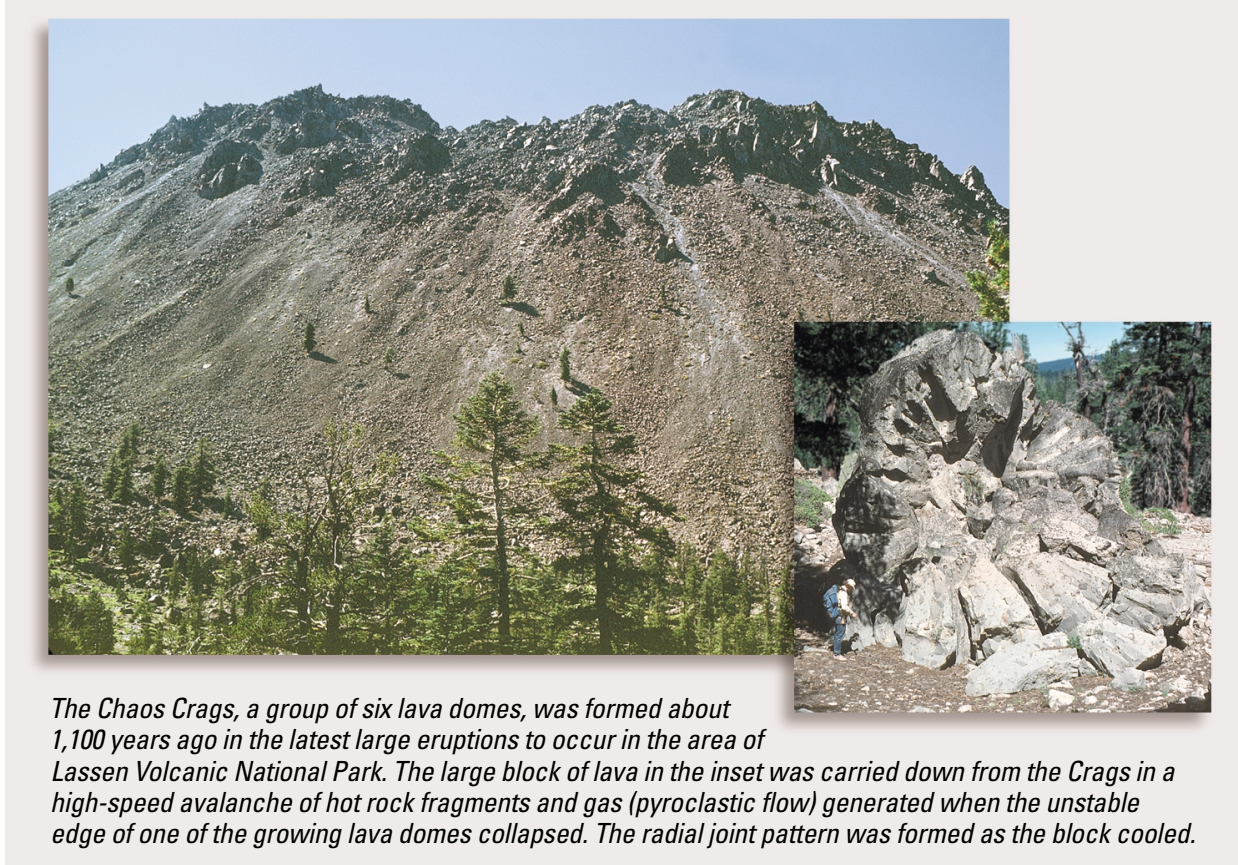

occurred at Lassen Peak between 1914 and 1917. The most recent large eruption produced Chaos Crags about 1,100 years ago. Such large eruptions in the Lassen area have an average recurrence interval of about 10,000 years. However, the geologic history of the Lassen area indicates that volcanism there is episodic, having periods of relatively frequent eruptions separated by long quiet intervals. For example, the last large event before the Chaos Crags eruption was the one that built Lassen Peak 27,000 years ago.

\section{What are the warning signs of an eruption?}

The most important sign of an impending volcanic eruption is seismic activity beneath the volcanic area. Seismologists can interpret subtle differences between earthquakes related to the rise of magma and the more familiar quakes of magma rising into the shallow subsurface might include increased release of volcanic gases from small openings called fumaroles, such as those found in the Bumpass Hell area of Lassen Volcanic National Park, and changes in the gas composition. Deformation of the ground surface in the vicinity of a volcano may also indicate that magma is approaching the surface. Typically, these warning signs appear a few weeks to months before an eruption, but can last for decades or even centuries without leading to an eruption. caused by tectonic faulting. Other warning signs

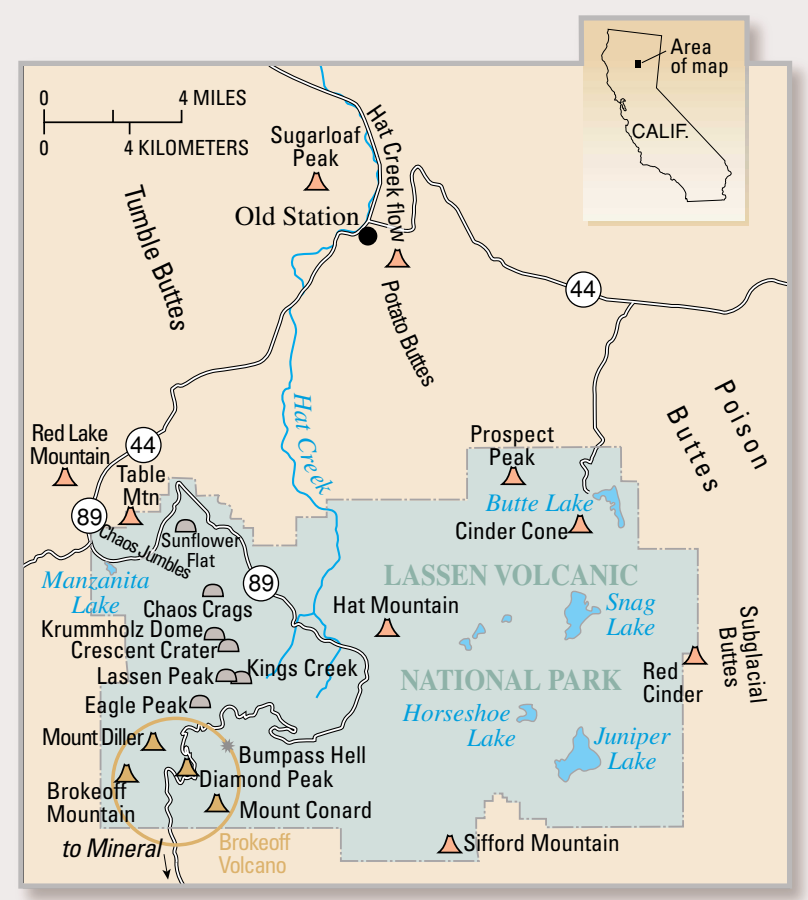

\section{VOLCANIC SITES IN THE LASSEN REGION AND ERUPTIONS IN THE PAST 50,000 YEARS}

The Lassen region has been volcanically active for more than 3 million years. The Lassen "volcanic center" began to erupt about 600,000 years ago. From 600,000 to 400,000 years ago, eruptions built a large volcano, often referred to as "Brokeoff Volcano" or "Mount Tehama" (outlined by brown circle). Later, this volcano became inactive and was mostly eroded away, leaving remnants that include Brokeoff Mountain, Mount Conard, Mount Diller, and Diamond Peak. Subsequent eruptions in the Lassen volcanic center have formed more than 30 steep-sided lava domes (the Lassen dome field). The most recently active parts of the volcanic center are Lassen Peak and other young domes formed in the past 50,000 years.

\section{Domes and pyroclastic flows (high-silica eruptions) \\ $\triangle$ Cones and lava flows (low-silica eruptions)}

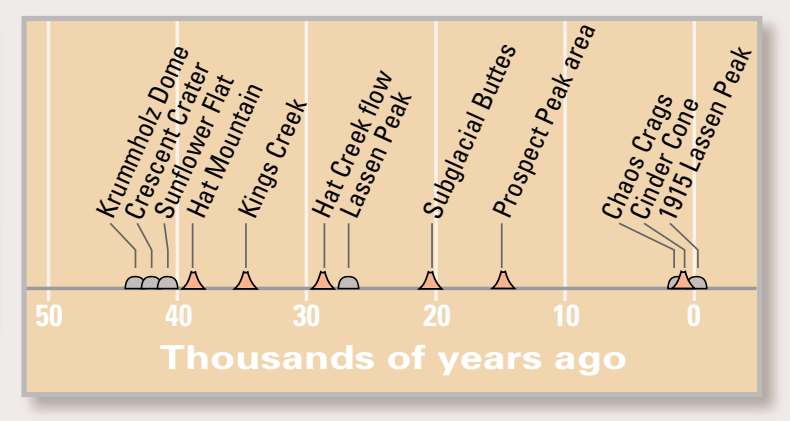




\section{VOLCANO HAZARD ZONES OF THE LASSEN VOLCANIC NATIONAL PARK REGION}
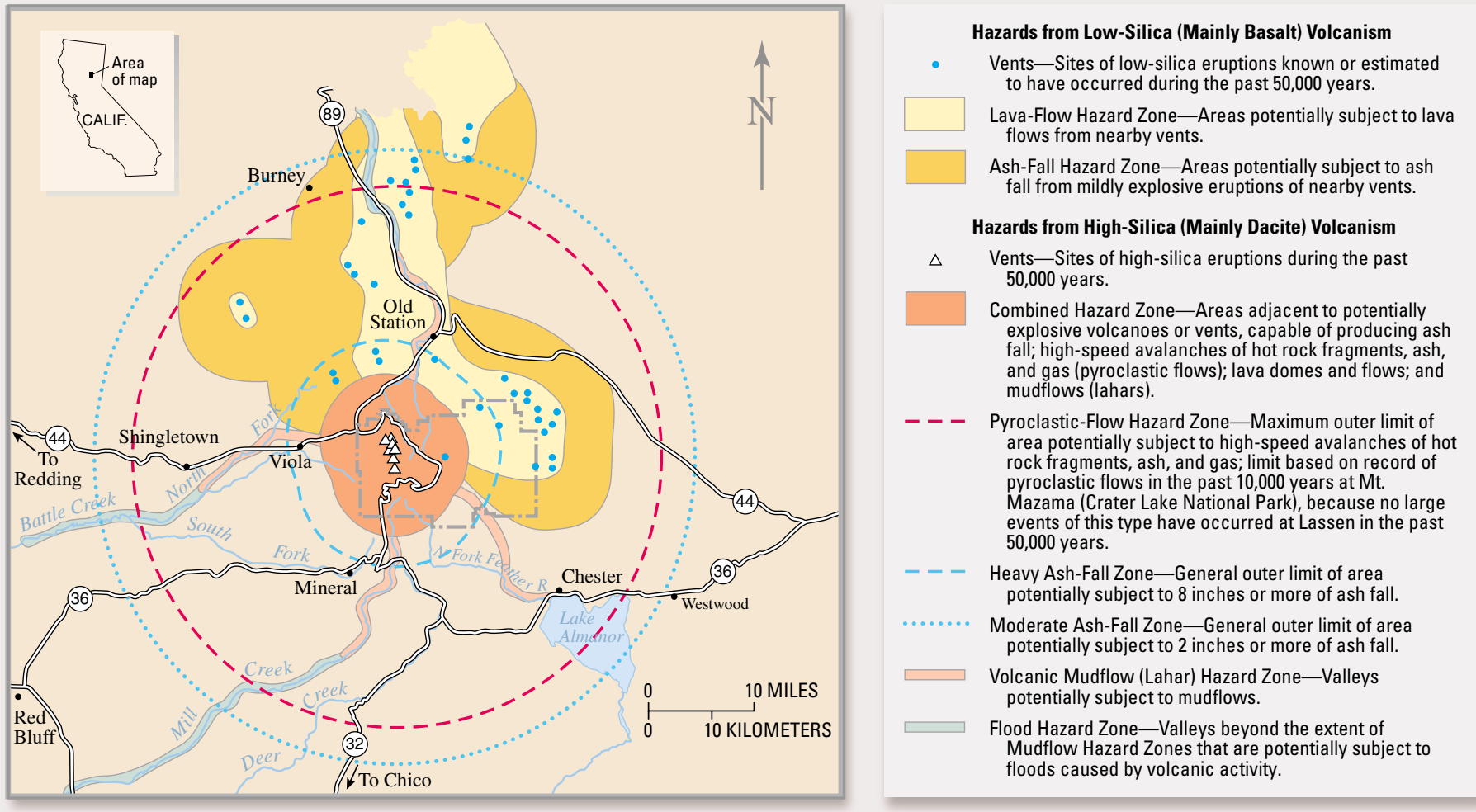

The areas of highest hazard in the region of Lassen Volcanic National Park are those that could potentially be affected by pyroclastic flows and mudflows. These areas are those in the immediate vicinity and downhill from likely eruption sites. Fallout of ash will affect areas downwind at the time of an eruption. Within the hazard zones, relative hazard is gradational, decreasing away from the location of potential vents.

What is being done to monitor the Lassen volcanic center?

After the eruption of Mount St. Helens in 1980, the U.S. Geological Survey (USGS) intensified its monitoring of active and potentially active volcanoes in the Cascade Range. Monitoring of the Lassen area includes periodic measurements of ground deformation and volcanicgas emissions and continuous transmission of data from a local network of nine seismometers to USGS offices in Menlo Park, California. Should indications of a significant increase in volcanic activity be detected, the USGS will immediately deploy scientists and specially designed portable monitoring instruments to evaluate the threat. In addition, the National Park Service (NPS) has developed an emergency response plan that would be activated to protect

\section{ASH FALL FROM ERUPTIONS IN THE LASSEN REGION 600,000 YEARS AGO}

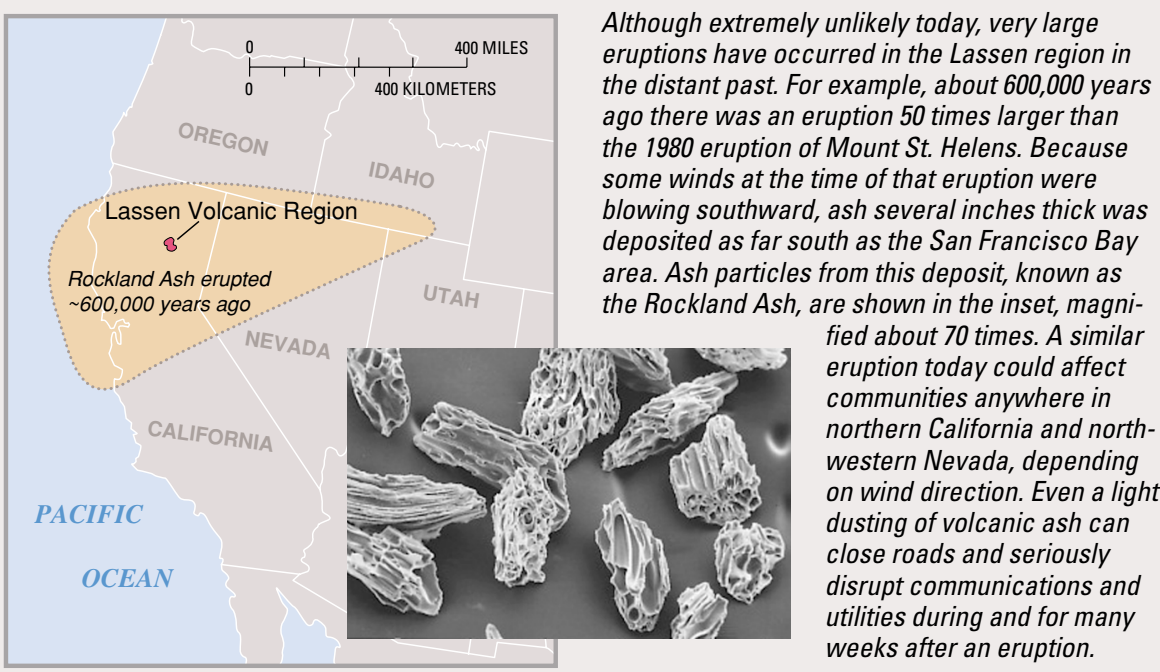

the public in the event of an impending eruption.

Recent work by scientists with the USGS in cooperation with the NPS is shedding new light on volcano hazards in the Lassen Volcanic National Park area. The work of these USGS scientists is only part of the USGS Volcano Hazards Program's ongoing efforts to protect people's lives and property in all of the volcanic regions of the United States, including the Pacific Northwest, eastern California, Wyoming, Alaska, and Hawaii.

Michael A. Clynne, Robert L. Christiansen, C. Dan Miller, Peter H. Stauffer, and James W. Hendley II

Graphic design by

Sara Boore and Susan Mayfield Banner design by Bobbie Myers

COOPERATING ORGANIZATIONS Lassen Park Foundation National Park Service U.S. Forest Service

For more information contact: U.S. Geological Survey David A. Johnston Cascades Volcano Observatory 5400 MacArthur Blvd., Vancouver, WA 98661 Tel: (360) 993-8900, Fax: (360) 993-8980 http://vulcan.wr.usgs.gov

U.S Geological Survey Volcano Hazards Program http://volcanoes.usgs.gov

See also What are Volcano Hazards? (USGS Fact Sheet 002 97), Eruptions of Lassen Peak, California, 1914 to 1917 (USGS Fact Sheet 173-98), and How Old is "Cinder Cone"? - Solving a Mystery in Lassen Volcanic National Park, California (USGS Fact Sheet 023-00). 